\title{
Longitudinality in childcare provided through Family Health Strategy
}

\author{
Longitudinalidade do cuidado à criança na Estratégia Saúde da Família \\ Londitudinalidad del cuidado al niño en la Estrategia de Salud de la Familia
}

GE Revista Gaúcha

de Enfermagem

\author{
Elenice Maria Cecchetti Vaz ${ }^{\mathrm{a}}$ \\ Rafaella Karolina Bezerra Pedrosa Magalhães ${ }^{b}$ \\ Beatriz Rosana Gonçalves de Oliveira Toso ${ }^{c}$ \\ Altamira Pereira da Silva Reichert ${ }^{d}$ \\ Neusa Collet ${ }^{d}$
}

DOl: $\quad$ http://dx.doi.org/10.1590/1983-

1447.2015.04.51862

\footnotetext{
aniversidade Federal Fluminense (UFF), Escola de Enfermagem Aurora de Afonso Costa, Departamento de Enfermagem Materno-Infantil e Psiquiátrica. Niterói, Rio de Janeiro, Brasil.

b Universidade Federal da Paraíba (UFPB), Departamento de Enfermagem de Saúde Pública e Psiquiatria João Pessoa, Paraíba, Brasil.

c Universidade Estadual do Oeste do Paraná (UNIOESTE), Programa de Pós-Graduação Biociências e Saúde. Cascavel, Paraná, Brasil.

d Universidade Federal da Paraíba (UFPB), Departamento de Enfermagem de Saúde Pública e Psiquiatria Programa de Pós-Graduação em Enfermagem. João Pessoa, Paraíba, Brasil
}

\section{ABSTRACT}

Objective: to evaluate the longitudinality attribute in childcare provided through the Family Health Strategy.

Method: quantitative survey performed with 344 caregivers of children below 10 years old, registered in the family health strategy of Distrito Sanitario III in João Pessoa, Paraiba. Data were collected from July to December, 2012, from the Brazil PCATool child version form and analyzed using descriptive statistics.

Results: among the aspects evaluated, it is highlighted that $89.5 \%$ of caregivers said they were consulted by the same professionals, and $81.9 \%$ felt good talking to the professional. The average score for the longitudinality component was satisfactory, with a 6.6 value. Conclusion: the health facilities assessed are guided towards the longitudinality attribute, however, the target mean score was exactly the cutoff value, implying the need for a thoughtful look at the improvement of the attribute in the care of children under ten years.

Keywords: Primary Health Care. Child. Family health.

\section{RESUMO}

Objetivo: Avaliar o atributo longitudinalidade no cuidado à criança na Estratégia Saúde da Família.

Método: Pesquisa quantitativa realizada com 344 cuidadores de crianças menores de 10 anos, cadastrados na estratégia de saúde da família do Distrito Sanitário III de João Pessoa, Paraíba. Os dados foram coletados no período de julho a dezembro de 2012, a partir do formulário PCATool-Brasil versão criança, e analisados por estatística descritiva.

Resultados: Entre os aspectos avaliados, destaca-se que 89,5\% dos cuidadores afirmaram ser atendidos pelos mesmos profissionais nas consultas e $81,9 \%$ se sentem bem ao conversar com o profissional. 0 escore médio para 0 componente longitudinalidade foi satisfatório, com valor 6,6.

Conclusão: As unidades de saúde avaliadas estão orientadas para o atributo da longitudinalidade, entretanto, o escore médio atingido ficou exatamente no valor de corte, implicando a necessidade de um olhar atencioso para o aprimoramento do atributo na atenção à criança menor de dez anos.

Palavras-chave: Atenção primária à saúde. Criança. Saúde da família.

\section{RESUMEN}

Objetivo: evaluar el atributo longitudinalidad del cuidado a los niños en la Estrategia Salud de la Familia.

Método: investigación cuantitativa con 344cuidadores de niños menores de 10 años, registradas en la estrategia salud de la familia de la Jurisdicción Sanitaria III de João Pessoa, Paraíba. Los datos fueron recogidos de julio a diciembre 2012, a partir de la herramienta PCATool Brasil versión para los niños y analizados mediante estadística descriptiva.

Resultados: entre los aspectos evaluados, se destaca que el $89,5 \%$ de los cuidadores dijo que fueron tratados por los mismos profesionales en las consultas y el $81,9 \%$ se siente bien en hablar con el profesional. La puntuación promedio para el componente longitudinalidad fue satisfactoria, con valor de 6,6.

Conclusión: las unidades de salud evaluadas están orientadas para el atributo longitudinalidad, sin embargo, la puntuación promedio obtenida fue exactamente el valor de corte, lo que implica la necesidad de una mirada reflexiva a la mejora del atributo en el cuidado de los niños menores de diez años.

Palabras clave: Atención primaria de salud. Niño. Salud de la familia. 


\section{DINTRODUCTION}

Family Health Strategy (Estratégia Saúde da Família - ESF), the main policy for the implementation and organization of primary health care (Atenção Primária à Sáude - APS) in Brazil, has been consolidated as an important reorientation of the Brazilian health care model, becoming the center of health care networks ${ }^{(1-2)}$.

This strategy has been essential to the effectiveness of the Unified Health System (SUS) as a way of organizing health services and improving the lives of users, considering their biopsychosocial context and treating them as social subjects in their individuality, complexity and culture, covering thereby, promoting, prevention, diagnosis and health treatment ${ }^{(3)}$.

The APS incorporates the principles of SUS and stands out with guidelines that create a new way of producing health actions and services, in the change of perspective and conversion of the mechanical and biomedical assistance model, in a model of public health that is multidisciplinary and focused on family and community ${ }^{(4-5)}$. It is considered of quality when made up of four key attributes, sized at: attention to the first contact, longitudinality, completeness and coordination, and three derived attributes: family centralization, community orientation and cultural competence(6).

The longitudinality attribute, a central feature of APS, is understood as the regular contributions made by health care staff and their consistent use over time in a mutual relationship between health staff, individuals and families. A therapeutic relationship characterized by responsibility on the part of health professionals and trusted by the user is implied in this follow-up. The primary means of performing longitudinal care is the staff know the user entered in context with their biopsychosocial, economic and cultural characteristics ${ }^{(6)}$.

From the perspective of longitudinality, forming this link is essential for there to be trust between service / health care professional and user, making this user relate to the service as a synonym of prevention, treatment and diagnosis of their disease ${ }^{(7)}$.

The longitudinality characteristics are consistent with what is expected in the ESF, which aims to provide health care for the entire family and community, meeting their basic needs for health care. From this perspective, health services and the developed actions are essential to prevention and health promotion of the child as it is strategic, being the main point of care with greater capillarity and potential to identify the health needs of the population $^{(8)}$. A study ${ }^{(9)}$ shows large numbers of child hospital- izations for causes that are sensitive to primary care and reflect a low efficiency of primary care services in relation to the service opportunity.

Therefore, in addition to the discussion about the reorganization of primary health services, one also needs to evaluate the results of these assessments because they can provide important data that will lead to increased quality and effectiveness of services provided. Thus, research development that measures the quality of the care longitudinality attribute becomes relevant because it can show the relationship degree established between professionals, users and services in APS. Considering the above, the question is: is there a longitudinal link between the user, professional and health care in the ESF? Thus, the objective of this study was to evaluate the longitudinality attribute in child care provided by the Family Health Strategy.

\section{METHODOLOGY}

It is a cross-sectional study with a quantitative approach, evaluation of the longitudinality attribute in FHS child care. The study was conducted among 53 Family Health Units (USF) of Distrito Sanitário III (DS-III), the largest primary care network in the city of João Pessoa - Paraiba, in the period from July to December, $2012^{(10)}$.

The study subjects were family members (father, mother) and / or caregivers (grandparents, uncles, legal caregivers) of children under ten years old registered in said family health units, selected by systematic sampling in the waiting line to trate the child, always beginning the interview from the last in line until the sample quota was established for each unit. The sample size calculation was based on the population of children aged up to 9 years, 11 months and 29 days, seen within six months prior to the collection of research data stage, a total of 21,486 consults. The sample was drawn by simple random probability sampling stratified with proportional share of the number of children enrolled in each of the 53 USFs, being made up of 344 families and / or caregivers.

To collect data, two instruments were applied: one with demographic data of the families and another called Primary Care Assessment Tool (PCATool) -Brazil child version. The answers of the instrument were Likert type, with a score of 1 to 4 for each element that makes up the attribute: definitely yes (4); probably (3); probably not (2); certainly not (1).

In this study we analyzed item D of the PCATool form corresponding to 14 questions that address the longitudinality attribute of APS. Data were double entered and analyzed in the form of descriptive statistics with distribution 
of absolute and relative frequencies, mean and median, considering a sampling error of 5\% and $95 \%$ confidence level, and entered into a spreadsheet of the Microsoft Excel 2010 program. The results were presented in tables and compared with available literature on the subject in question. The final score for each indicator of the PCATool Brazil child version instrument was given by averaging the values of the answers of each respondent.

To obtain the score of the essential longitudinality attribute in the APS, the medium of the items of this attribute was calculated. For this purpose, it was first necessary to reverse the D10 value of the item so that the larger the value (response) assigned, the lower would be the orientation for the APS. After inversion, the score for this attribute was calculated by adding the value of the items divided by the number of items to produce a mean score. The value obtained was transformed into a scale of 0-10 (score obtained-1) $\times 10 / 3^{(11)}$, the scores $\geq 6.6$ are considered high or satisfactory values, and values $<6.6$ were considered low or unsatisfactory.

This research was developed in accordance with the standards of the National Health Council Resolution 196/96 ${ }^{(12)}$, approved by the Research Ethics Committee Opinion N. 044/2012-CEP. The research subjects signed a Free and Informed Consent Form.

\section{RESULTS}

Among the data on sociodemographic characteristics of families, there is the low socioeconomic status, whereas $58.4 \%$ of households had a family income of up to one minimum wage. However, half of the sample (50.58\%) had education up to 10 years of schooling. It was observed that of the 344 caregivers of children, $45.35 \%$ of mothers had only one child, while $33.43 \%$ had two children, $13.08 \%$ of mothers had interval between births and varying by up to two years.

To reference the study subjects, it was decided to use the term "mothers" rather than child caregivers, considering that the majority of the sample consisted of the mothers of the children (80.29\%).

In the PCATool-Brazil version child form for 14 variables that make up the item on the longitudinality attribute. Among them, those that obtained better results when analyzed individually (above 7.0) and are related to communication / relation dialogue between professionals and the mothers of children were: care by the same professional; professional understands the questions; professional responds understandably so; professional gives time to listen to the problems; mother feels comfortable with the profes- sional; professional knows the child as a person; professional understands the mother's questions; professional knows the medical history of the child; and professional knows the medications the child uses.

Among the variables with lower performance (less than 6.0) that address the professional relationship of health and the child's family, are: switch to another service; professional knows the family; professional knows family problems; professional knows the occupation / job of family members; and professional knows of troubles the family faces to get medications. In this paper, we report only five of these variables with values that stood out.

In Table 1 are the absolute values and percentages relating to information about the items related to the longitudinality attribute present in the PCATool instrument. When asked about the regularity of care of the child by the same professional, $89.5 \%$ of the mothers interviewed said that children are served by the same professionals in their referral units, therefore existing regularity in this service. In contrast, $6.4 \%$ are not served by the same professionals when seeking health care. When asked if mothers feel free to raise concerns about the child's health with the care professional, $81.9 \%$ did not feel comfortable asking. The professional category most often cited by mothers was the professional nurse, with $52.9 \%$ of respondents, followed by $23.8 \%$ referring to physicians. When asked if the health professional responds to questions from mothers in an understandable matter, 83.9\% answered that they can understand the responses of professionals, while 3.2\% reported that the health professional did not understand. Nurses stand out like the pros that make themselves the most understandable (53.1\%).

Regarding the opinion of mothers about the possibility of changing the unit / health care professional, if that were possible, 53.9\% of the survey participants said they definitely would not change the service and / or health care professional, while $308 \%$ would like this change to happen. It stands out in the responses that $36.2 \%$ of mothers would not change nurses. Regarding access to prescribed drugs, $40.4 \%$ of mothers said that professionals are unaware of the difficulties in obtaining medicines, and 37.6\% reported that health professionals recognize if they can or can not afford to buy the medication. Of these professionals, 24.8\% of mothers claim that nurses know the conditions for obtaining the drugs.

The average longitudinality attribute score obtained in the family health units of João Pessoa - Paraiba, Brazil, is 6.6 presenting a satisfactory result $(\geq 6,6)$, suggesting that APS is oriented in this attribute. 
Table 1 - Absolute frequency and percentage regarding the longitudinality attribute, Joao Pessoa, Brazil, 2013

\begin{tabular}{|c|c|c|c|c|c|c|c|c|c|}
\hline \multirow{2}{*}{ Variables } & & \multicolumn{2}{|c|}{ Certainly Not } & \multicolumn{2}{|c|}{ Probably not } & \multicolumn{2}{|c|}{ Probably } & \multicolumn{2}{|c|}{ Yes } \\
\hline & & $\mathbf{N}$ & $\%$ & $\mathbf{N}$ & $\%$ & $\mathbf{N}$ & $\%$ & $n$ & $\%$ \\
\hline \multirow{5}{*}{$\begin{array}{l}\text { Regularity of service by } \\
\text { the same professional }\end{array}$} & Nurse & 7 & 2 & 3 & 0.9 & 3 & 0.9 & 192 & 55.8 \\
\hline & Doctor & 8 & 2.3 & - & - & 2 & 0.5 & 102 & 29.7 \\
\hline & USF & 4 & 1.2 & - & - & 3 & 0.9 & 12 & 3.4 \\
\hline & Other & 3 & 0.9 & 2 & 0.6 & - & - & 2 & 0.6 \\
\hline & Total & 22 & 6.4 & 5 & 1.5 & 8 & 2.3 & 308 & 89.5 \\
\hline \multirow{5}{*}{$\begin{array}{l}\text { Feels free to expose } \\
\text { concerns }\end{array}$} & Nurse & 8 & 2.3 & 2 & 0.6 & 13 & 3.8 & 182 & 52.9 \\
\hline & Doctor & 17 & 4.9 & 4 & 1.2 & 10 & 2.9 & 82 & 23.8 \\
\hline & USF & 3 & 0.9 & - & - & 2 & 0.6 & 14 & 4 \\
\hline & Other & 1 & 0.3 & 1 & 0.3 & 1 & 0.3 & 4 & 1.2 \\
\hline & Total & 29 & 8.4 & 7 & 2.1 & 26 & 7.6 & 282 & 81.9 \\
\hline \multirow{5}{*}{$\begin{array}{l}\text { Understanding } \\
\text { responses }\end{array}$} & Nurse & 2 & 0.6 & 5 & 1.5 & 15 & 4.4 & 183 & 53.1 \\
\hline & Doctor & 6 & 1.7 & 6 & 1.7 & 10 & 2.9 & 91 & 26.5 \\
\hline & USF & 3 & 0.9 & 2 & 0.6 & 2 & 0.6 & 12 & 3.4 \\
\hline & Other & - & - & 2 & 0.6 & 2 & 0.6 & 03 & 0.9 \\
\hline & Total & 11 & 3.2 & 15 & 4.4 & 29 & 8.5 & 289 & 83.9 \\
\hline \multirow{5}{*}{$\begin{array}{l}\text { Would change the } \\
\text { service if possible }\end{array}$} & Nurse & 125 & 36.2 & 16 & 4.8 & 15 & 4.3 & 48 & 14 \\
\hline & Doctor & 52 & 15.1 & 12 & 3.5 & 3 & 0.9 & 44 & 12.7 \\
\hline & USF & 7 & 2 & 2 & 0.6 & - & - & 10 & 2.9 \\
\hline & Other & 2 & 0.6 & 1 & 0.3 & - & - & 4 & 1.2 \\
\hline & Total & 186 & 53,9 & 31 & 9.2 & 18 & 5.2 & 106 & 30.8 \\
\hline \multirow{5}{*}{$\begin{array}{l}\text { Professional knows } \\
\text { the problems in } \\
\text { obtaining drugs }\end{array}$} & Nurse & 68 & 19.8 & 18 & 5.2 & 27 & 7.8 & 85 & 24.8 \\
\hline & Doctor & 57 & 16.6 & 8 & 2.3 & 8 & 2.3 & 38 & 11 \\
\hline & USF & 10 & 2.8 & 4 & 1.2 & 1 & 0.3 & 4 & 12 \\
\hline & Other & 4 & 1.2 & 1 & 0.3 & - & - & 2 & 0.6 \\
\hline & Total & 139 & 40.4 & 31 & 9 & 36 & 10.4 & 129 & 37.6 \\
\hline
\end{tabular}

Source: Data bank of the survey Avaliação da efetividade da atenção primária em saúde para crianças, João Pessoa, 2013.

\section{DISCUSSION}

The Family Health Strategy model chosen by the Brazilian government for primary health care and qualitative monitoring of the health of the population, has, in longitudinality, an essential factor for the health system factor because this attribute tends to produce more accurate diagnoses and treatments, as well as reducing unnecessary referrals to specialists and performing more complex procedures ${ }^{(13)}$.

To create the longitudinal link, the health team must know the user, so that it can have their health problems resolved, and their disease prevention and health promo- tion. The results of this study indicate regular service by professionals in health facilities surveyed, which may favor the establishment of a bond and, with it, the greater possibility of longitudinal care. Nurses were indicated as the health team professionals who establish more relationship with users. A study ${ }^{(14)}$ points out that the practice of nurses in the FHS has a social importance, especially with regard to the population's health-disease process, and that their actions are very important to restructure this care model.

The welcoming of the user by the service brings positive aspects to the user interface / professional / service because it enables decision-making and availability to be heard by the health team, with guidance and accessible language. 
This welcoming extends the possibilities of participation and user autonomy in treatment, recognizing itself as the subject of care that is being provided ${ }^{(15)}$. Good care, based on listening to the child's family, and good professional performance provide the link with the health service. Thus, it optimizes the service because when professionals know the users and the priorities of each one, it facilitates their access $^{(16)}$ according to their unique demands.

For this, the professional must use effective communication, because this is an essential factor for the establishment of the longitudinal link. It is therefore necessary to develop an accessible dialogue relationship, for mothers of children to understand the information provided during the meeting with the professional, and feel comfortable to talk about their concerns, for as long as deemed necessary.

This research shows that most mothers of children feel at ease to express their concerns and to understand the way the provider responds to their questions. When professionals communicate with parents / guardians in a clear and objective way, it enables the understanding necessary for effective child care, contributing to the resolution of child health problems ${ }^{(17)}$, strengthening the longitudinal link.

The data also reveal that the professionals have responded to the questions of the mothers of children with easily understandable language, this aspect being evaluated as satisfactory in health care provided by ESFs under study. In that sense, in order to establish a productive dialogue, all health care professionals need to use words that facilitate the understanding of the children's mothers as well as open spaces of qualified hearing to enhance their health concerns of their children.

A study ${ }^{(18)}$ held in Sao Paulo on this attribute brought positive scores that indicated that the mothers felt that the doctors and nurses understood their questions related to the children's health, and also that they understand the responses of professionals to their questions. Mothers of children reported that they had enough time to express their concerns to members of the health team that, in turn, knew the history of their children, and treated them not as a health issue but as a human being.

The establishment of the relationship between professional and user becomes positive when there is confidence and trust and, therefore, the longitudinality should be effective ${ }^{(7)}$. Continuity of care increases user satisfaction with the service, making him return. However, this study showed that some mothers of children would change service / professional if that were possible. The isolated analysis of this item can demonstrate that there is weakness of the ESF in regards to the satisfaction of some families of children in relation to the service. A study ${ }^{(19)}$ with the objective of identifying the therapeutic itinerary of families of children with respiratory diseases, indicated that the longitudinality attribute has not been established in an efficient way, because in many cases, when seeking care in the ESF, the children's parents did not find the medical unit and were referred to other health services where the professionals were unaware of the clinical history of the child. Thus, the level of dissatisfaction of children's parents in relation to the service grew.

For optimum control of the service provided in the EFS, some aspects of the longitudinality should be reviewed with a focus on better health care for the child. It was found that some nurses and doctors are unaware of the family's difficulty in acquiring a prescribed medication. Health professionals should be aware of the financial conditions of the users and their ability to access to prescription drugs because the longitudinal care requires each team to fit their therapeutic approaches to the reality of the families under their care responsibility ${ }^{(7)}$.

The longitudinality presents benefits to the health system, in recognition of user needs; reduce costs and hospitalizations; better prevention and health promotion, and greater user satisfaction. So, trust between professionals and users is established over time, making it more comfortable to expose their problems and accept the recommendations. Similarly, when the professional knows the user, they arrive quickly to assess the problem. This is positive, since for the child's health care a more precise interaction with the family and the child's life history is needed ${ }^{(2,20)}$.

Although some items of the form present isolated values that bring a reflection for improving the care of children, such as knowledge by healthcare professionals about the access of users to buy prescription drugs, the score assigned to longitudinality in the ESF studied received a value of 6.6, considered as satisfactory. This data is very important because due to the fact that longitudinality is a central feature of the APS, and the results reveal the potential of services studied to achieve the desired resolution and quality. However, despite the attribute being satisfactory, the average score is in the cut-off limit (6.6), suggesting that there be greater attention to the longitudinality, for a substancial establishment may provide a more effective assistance to children's health .

The resoluteness in ESF refers to the set of actions that promote user satisfaction, the creation of the link and that they have quality of care as a guide in the organization of the work process. These actions create positive media for this attribute to be set efficiently, and insight, befitting the assumptions of the APS. 


\section{-CONCLUSION}

The longitudinality is related to the effectiveness of the APS, and the evaluation of this attribute in different assistance models in effect in Brazil. The survey reveals that longitudinality at the units is being established to the satisfaction of a strengthened APS, although it still has a long way to go, given that its score is in the cut off point of the assessment. The full care for children requires special attention to their specificities in order to ensure adequate and quality assistance.

Knowing that the ESF is an adequate space to promote child health, the way care is organized in regards to longitudinality needs to be reviewed, seeking to offer greater quality services to the population. However, this research does not end with the present results, but it does offers subsidies so that formulators of public health policies can rethink longitudinality in today's health services aimed at child care. Research needs to move forward on this issue including health professionals in the data collection process, because their perception is crucial for the qualification and reorganization of the Family Health Strategy services.

\section{DEFERENCES}

1. Gomes KO, Cotta RMM, Araújo RMA, Cherchiglia ML, Martins TCP. Atenção Primária à Saúde - a "menina dos olhos" do SUS: sobre as representações sociais dos protagonistas do Sistema Único de Saúde. Ciênc Saúde Coletiva [Internet]. 2011[cited 2013 mar 20];16(1):881-92. Available in: http://www.scielo.br/ $\mathrm{pdf} / \mathrm{csc} / \mathrm{v} 16 \mathrm{~s} 1 / \mathrm{a} 20 \mathrm{v} 16 \mathrm{~s} 1 . \mathrm{pdf}$

2. Leão CDA, Caldeira AP, Oliveira MMC. Atributos da atenção primária na assistência à saúde da criança: avaliação dos cuidadores. Rev Bras Saúde Matern Infant. 2011;11(3):323-34.

3. Silva K, Sena RR, Grillo MJC, Horta NC. Formação do enfermeiro: desafios para a promoção da saúde. Esc Anna Nery Rev Enferm. 2010;14(2):368-76.

4. Henrique F, Calvo MCM. Avaliação do Programa Saúde da Família nos municípios de Santa Catarina, Brasil. Cad Saúde Pública. 2008;24(4):809-19.

5. Veloso RC, Araújo MRN. Avaliação da resolutividade do Programa Saúde da Família em municípios de pequeno porte no Estado de Minas Gerais. Rev APS. 2009;12(3):238-43.

6. Starfield B. Atenção primária: equilíbrio entre necessidades de saúde, serviços e tecnologia. Brasília: Unesco, Ministério da Saúde; 2002.

\section{Author's address:}

Elenice Maria Cecchetti Vaz

Rua Themístocles da Costa Brito, 235/601, Jardim Oceania

58.037-725 João Pessoa - PB

E-mail: elececchetti@ig.com.br
7. Linard AG, Castro MM, Cruz AKL. Integralidade da assistência na compreensão dos profissionais da Estratégia Saúde da Família. Rev Gaúcha Enferm. 2011;32(3):546-53.

8. Ministério da Saúde (BR). Documento de diretrizes para o cuidado das pessoas com doenças crônicas nas Redes de Atenção à Saúde e nas linhas de cuidado prioritárias. Brasília: Ministério da Saúde; 2012.

9. Barreto JOM, Nery IS, Costa MSC. Estratégia Saúde da Família e internações hospitalares em menores de 5 anos no Piauí, Brasil. Cad. Saúde Pública [Internet]. 2012 [citado 2013 mar 20];28(3):515-26. Disponível em: http://www.scielo. $\mathrm{br} / \mathrm{pdf} / \mathrm{csp} / \mathrm{v} 28 \mathrm{n} 3 / 12 . \mathrm{pdf}$

10. Magalhães, RKBP. Longitudinalidade do cuidado à criança nas unidades de saúde da família [trabalho de conclusão de curso]. João Pessoa (PB): Curso de Enfermagem, Universidade Federal da Paraíba; 2014.

11. Ministério da Saúde (BR). Manual do instrumento de avaliação da atenção primária à saúde: primary care assessment tool PCATool - Brasil. Brasília: Ministério da Saúde; 2010. p. 30-2.

12. Ministério da Saúde (BR). Conselho Nacional de Saúde. Resolução no 196, de 10 de outubro de 1996. Diretrizes e normas regulamentadoras de pesquisas envolvendo seres humanos. Diário Oficial [da] República Federativa do Brasil. 1996 out.16;134(201 Seção 1):21082-5.

13. Gérvas J, Fernández MP. El fundamento cientíico de la función de filtro del médico general. Rev Bras Epidemiol. 2006;9(1):144-51.

14. Schimith MD, Lima MADS. 0 enfermeiro na equipe de saúde da família: estudo de caso. Rev Enferm UERJ. 2009;17(2):252-6.

15. Pinafo E, Lima JVC, Baduy RS. Acolhimento: concepção dos auxiliares de enfermagem e percepção de usuários em uma unidade de saúde da família. Espaç Saúde. 2008;9(2):17-25.

16. Lima ADS, Ramos DD, Rosa RB, Nauderer TM, Davis R. Acesso e acolhimento em umidades de saúde na visão dos usuários. Acta Paul Enferm. 2007;20(1):12-7.

17. Knoll GF, Pires VL. Enunciação, intersubjetividade e gênero: análise dialógica de tiras de humor. Desenredo: Revista do Programa de Pós-Graduação em Letras da Universidade de Passo Fundo. 2012;8(1):218-34.

18. Furtado MCC, Braz JC, Pina JC, Mello DF, Lima RAG. Assessing the care of children under one year old in Primary Health Care. Rev Latino-am Enferm. [Internet]. 2013 [cited 2014 may 06];21(2):554-61. Available at: http://www.scielo.br/ pdf/rlae/v21n2/0104-1169-rlae-21-02-0554.pdf

19. Oliveira BRG, Collet N, Mello DF, Lima RAG. The therapeutic journey of families of children with respiratory diseases in the public health service. Rev Latino-am Enferm. [Internet]. 2012 [cited 2014 jan 25]; 20(3):453-61. Available at: http:// www.scielo.br/pdf/rlae/v20n3/a05v20n3.pdf

20. Starfield B, Shi L. Policy relevant determinants of health: an international perspective. Health Policy. 2002 [cited 2014 jan 25];60(3):201-18Available at: http://www.amsa.at/images/Starfield_internacional_perspective.pdf 